\title{
Pituitary Gland Paraganglioma
}

National Cancer Institute

\section{Source}

National Cancer Institute. Pituitary Gland Paraganglioma. NCI Thesaurus. Code C155769.

An extremely rare paragang lioma arising from chief cells of the dispersed paraganglia of the sellar region. (WHO 2017) 